\title{
Occurrence of landslides in Nepal and their mitigation options
}

\author{
Prem Bahadur Thapa \\ Department of Geology, Tri-Chandra Multiple Campus, Tribhuvan University, Kathmandu, Nepal \\ Email: geoscithapa@yahoo.com
}

\begin{abstract}
Landslides are very common occurrences in Nepal that have been affected development infrastructures, lives, and properties of the people every year. Many hill villages are situated on or adjacent to unstable slopes and old landslides are reactivated from time to time. The rapidly increasing construction of infrastructure, such as roads, irrigation canals, and dams without due consideration of natural hazards is contributing to triggering of landslides and debris flows. Thus, this paper has explored the cause and characteristics of landslides occurrences and their mitigation practices in Nepal. Topographic, geologic and triggering factors, and human intervention causing landslides are characterised to suggest the suitable mitigation options that can be implemented in the mountain hill-slopes. Among the wide range of slope stabilisation measures which are available to practitioner engineer, the lowering of groundwater level in combination of controlling of surface infiltration (e.g. sealing of tension cracks) of water into landslide are the most cost effective options for mountainous terrain because the rise in pore water pressure is one of the basic cause of landslides during the rainy season. In addition, removing of unstable slope debris, surface drainage, and retaining walls are the useful landslide mitigation measures depending on site conditions, availability of budget, and specific requirements. Various support systems and elements can be crafted for creative solutions of the slope instability problems in Nepal.
\end{abstract}

Keywords: Landslide, occurrence, mitigation option, Nepal

Received: May 18, 2015

Revision accepted: June 19, 2015

\section{INTRODUCTION}

Landslides are geologic hazards that occur on spatial and temporal scales in mountainous landscapes and are frequently responsible for considerable loss of life and property (McKean and Roering 2004). They are one of the most visible and destructive geomorphic processes in the mountain hillslopes (Aleotti and Chowdhury 1999, Lei and Jing-Feng 2006, Vijith et al. 2009). Combination of dynamic geology, intricate topography, and frequent extreme weather events has played a key role for the occurrence and reactivation of landslides in Nepal. Every year, especially during the monsoon season, landslides have been mostly affected development infrastructures, lives, and properties of the people. Many hill villages are situated on or adjacent to unstable slopes and old landslides that are reactivated from time to time. The rapidly increasing construction of infrastructure, such as roads, irrigation canals, and dams without due consideration of given natural hazards, is contributing to triggering of landslides and debris flows.

Mitigation measures of landslides proposed or implemented by government departments, non-government and international organisations, and academic institutions in Nepal differ considerably. Majority of landslide mitigation efforts were carried out without proper or optimum investigations and on hit and trial basis. The characteristics of various types of landslides are important to develop appropriate mitigation measures in the mountainous terrain of Nepal because the problems of landslides are different in different physiographic, geologic, and climatic zones (Upreti 2001). Therefore, the rational design of landslide mitigation cannot begin until the factors of site conditions are properly evaluated. Since 1950, increased development in hillside area has underlined the importance of understanding the geologic factors causing instability before beginning the engineering analysis or repair. Too often, sites prone to landslide have been reactivated and repeated mitigation measures were or are being attempted within a few years of the implementation which evidencing the sustainable landslide mitigation options need to be addressed.

\section{OCCURRENCE OF LANDSLIDES IN NEPAL}

The inherently weak geological characteristics of rocks and soils have made the Himalaya fundamentally a very fragile mountain (Upreti 2001) and the triggering factors such as rainfall and earthquakes play their role to make the mountain very vulnerable to landslides and other mass wasting processes. The combination of the weak geology and the Monsoon climate makes each physiographic zone of Nepal unique in their characteristics of occurrence of landslides. Geological structures such as thrusts, faults, folds, and joints in general make any rock of the Himalaya physically weak (Upreti 2001). Actually the landslides are not only the main natural hazard in Nepal that threatening the lives and properties and they are also the process of geomorphic evolution of landforms in the Himalayan landscape over an extended span of time. The unstable landforms formed by all these geomorphic processes will ultimately failed under the influence of gravity or triggering factors in the form of landslides and other types of mass movements. Thus, landsliding is so common that it can be considered as the norm rather than the exception in the Himalayan regions (Brooks and Lawrance 1986). 
Nepal suffers from a large numbers of landslides especially during the late monsoon period when pore water pressure builds up in the hill-slope mass or catastrophic earthquake happens. Spatial distribution of pre-earthquake landslides in Nepal is shown in Figure 1. Available landslide and related hazards database (DesInventar) during the period from 1971 to 2015 shows that average loss of life is about 200 per year in Nepal and one of the most devastating landsliderelated hazards in July 1993 (e.g. Fig. 2a) that killed 1336 people in the central Nepal (Chhetri and Bhattarai 2001). On 2 August 2014, a massive landslide at Jure, Sindhupalchowk District in the central Nepal was caused by rainfall event, the deadliest in the country's history that a single landslide killed 146 peoples, buried the Arniko Highway and created a high artificial dam about $3 \mathrm{~km}$ long across the Sunkoshi River and blocking the flow of water completely for nine hours (Fig. 2b). Due to repeated occurrence of catastrophic slope failures in Nepal, it is important to monitor or investigate the instability indications which might give clue to precursor of transient failure. For example, developments of alluvial fan at the down-slope of stream which makes confluence to other river and drunken trees in the hill-slopes indicate potential sites of future slide (Fig. 3a, b). If any indications had known in case of Jure Landslide or other slides in the Nepal, significant number of fatalities and loss of properties could be minimised. In addition to landslides occurred during rainy seasons, recent 2015 Gorkha Earthquake triggered thousands of landslides across the central Nepal.

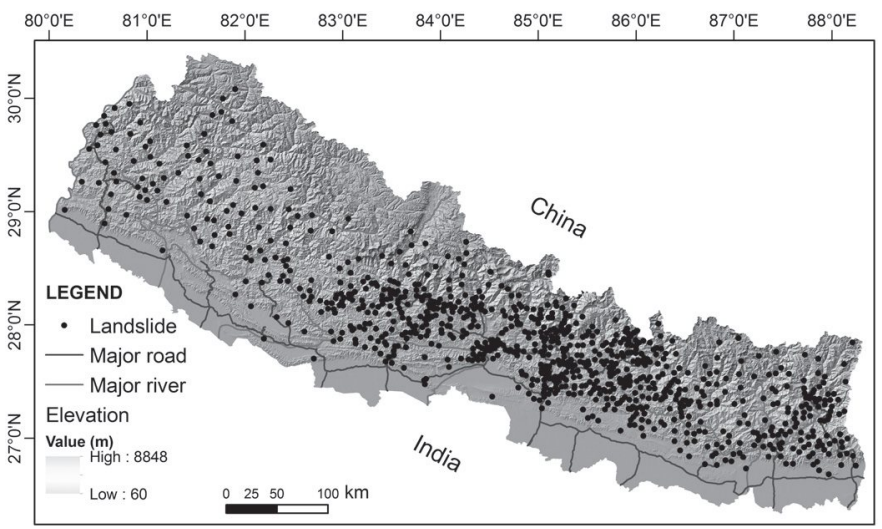

Fig. 1: Spatial distribution of pre-earthquake (before 2015 Gorkha Earthquake) landslides in the Nepal Himalaya. (Source: DesInventar, MoHA，DWIDP，LRA/DoLIDAR/ Scott Wilson 2002, Dahal and Hasegawa 2008)

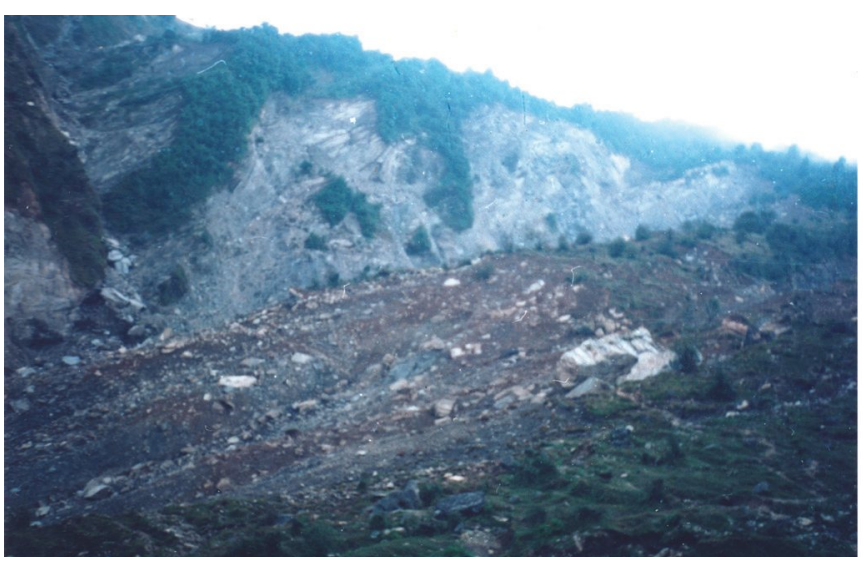

(a)

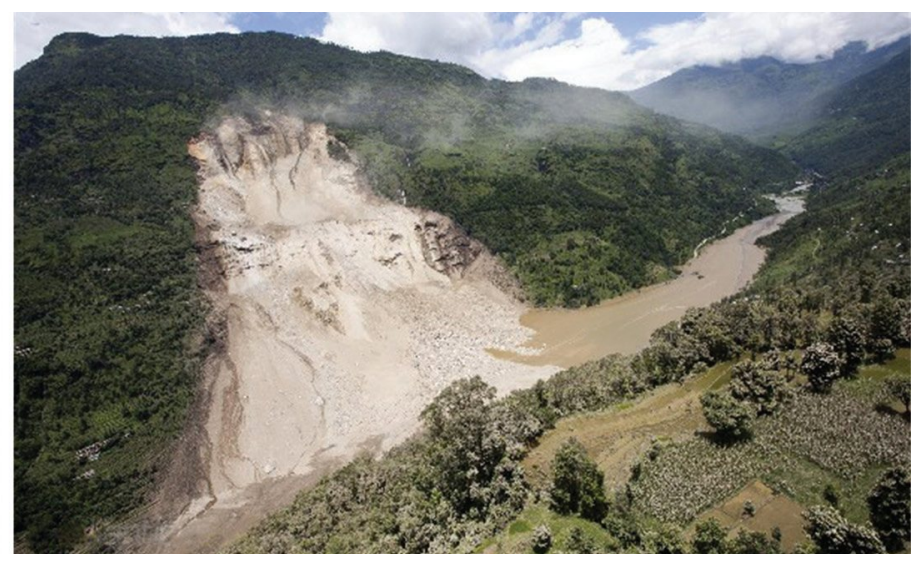

(b)

Fig. 2: Noticeable landslides in Nepal (a) landslide at Chisapani village, Makawanpur caused by the 19-21 July 1993 water-induced disaster and (b) huge landslide at Jure, Sindhupalchawk on 02 August 2014.

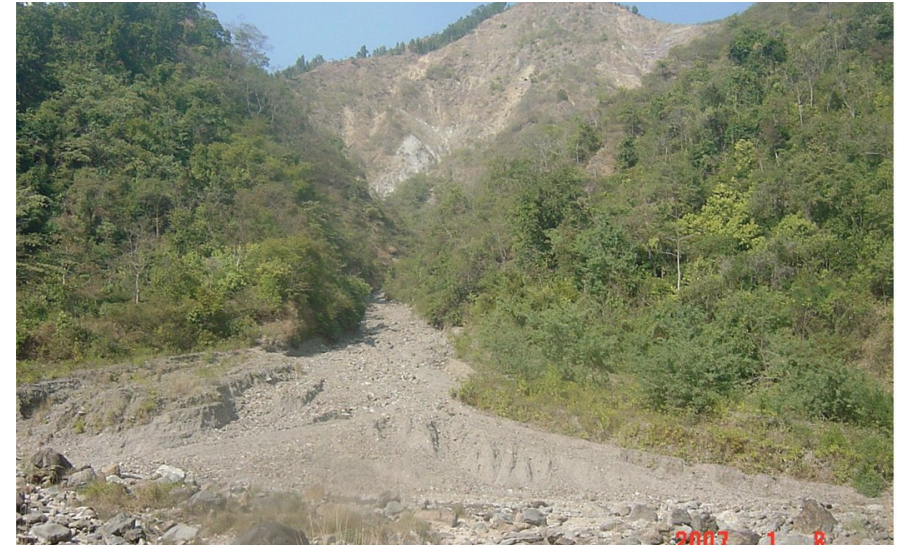

(a)

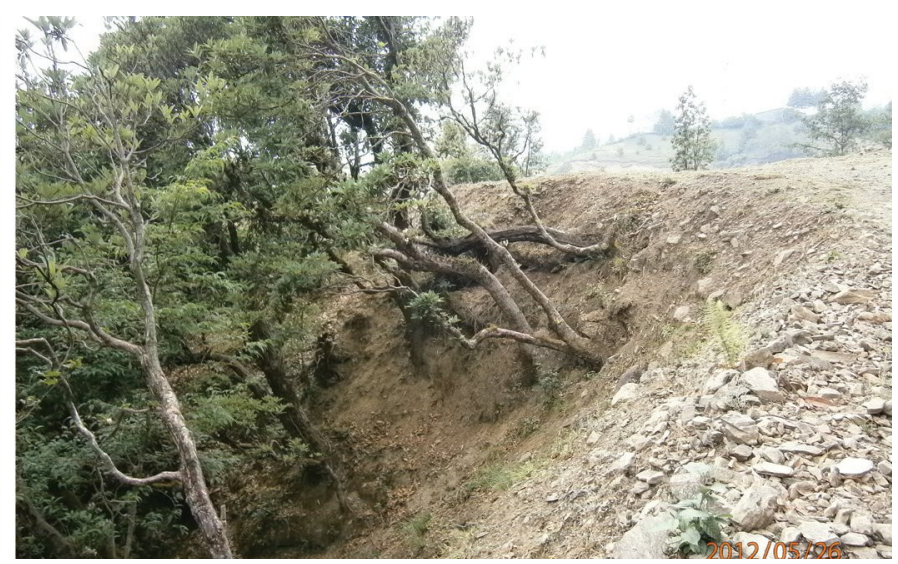

(b)

Fig. 3: Indications of hill-slope instability in mountainous terrains (a) alluvial fan and (b) drunken trees. 
Occurrence of landslides in Nepal and their mitigation options

\section{Topographic and geologic control}

The rugged topography and fragile geology play vital role for the occurrence of landslides in Nepal. The landslide probability generally influenced by slope gradient and a case study in the central Nepal showed that predominant occurrences of landslides are found in the slope angle range from 25 to 35 degrees (Fig. 4a). Hillslope orientation is also the topographic factor and shows a strong inheritance from bedrock structure, especially by bedding or metamorphic foliation because the

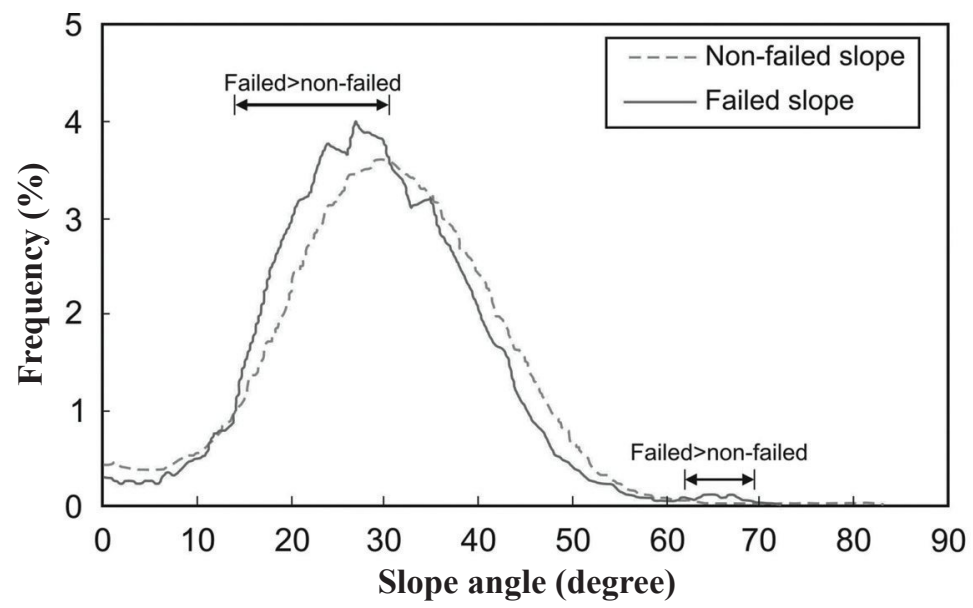

(a)

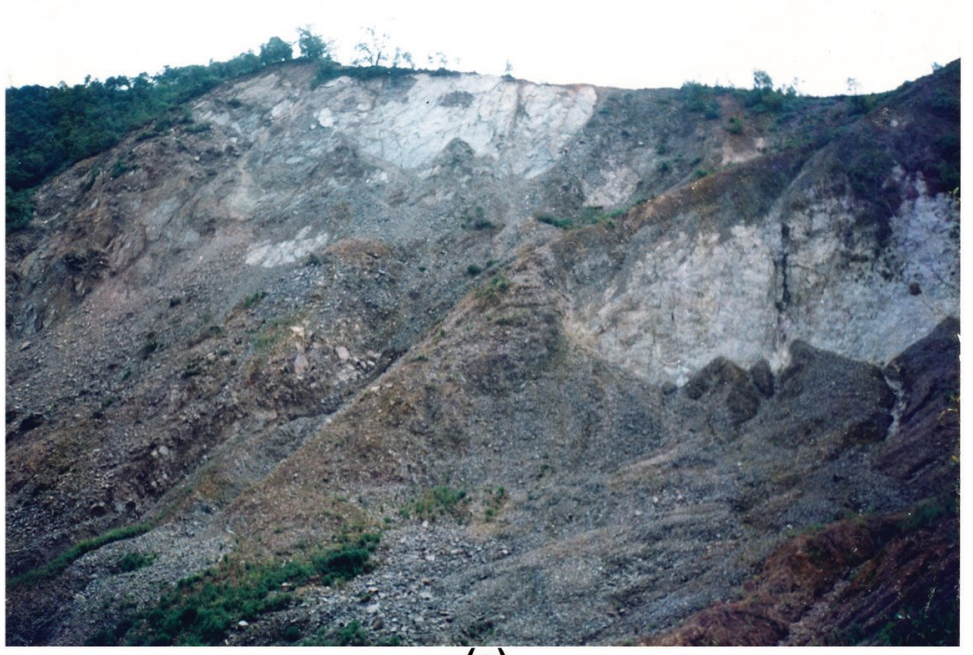

(c)

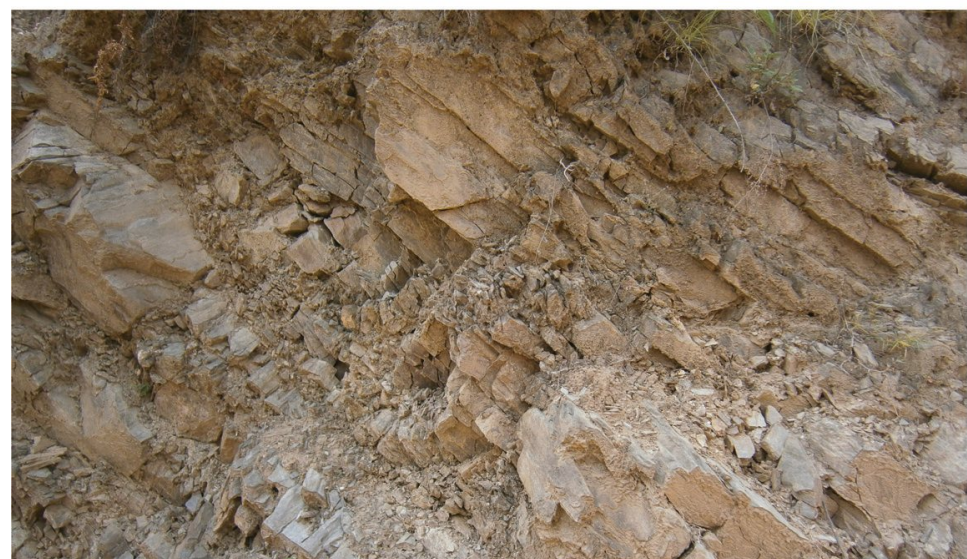

(e)

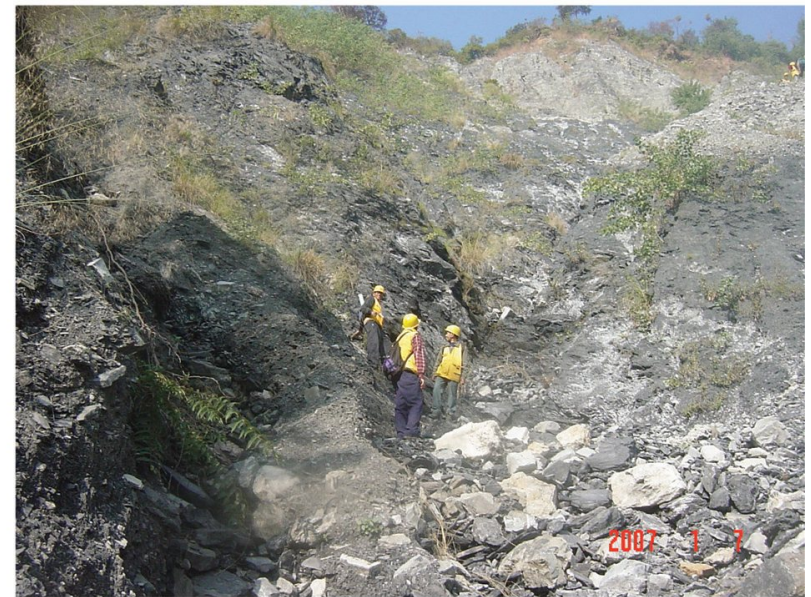

(b)

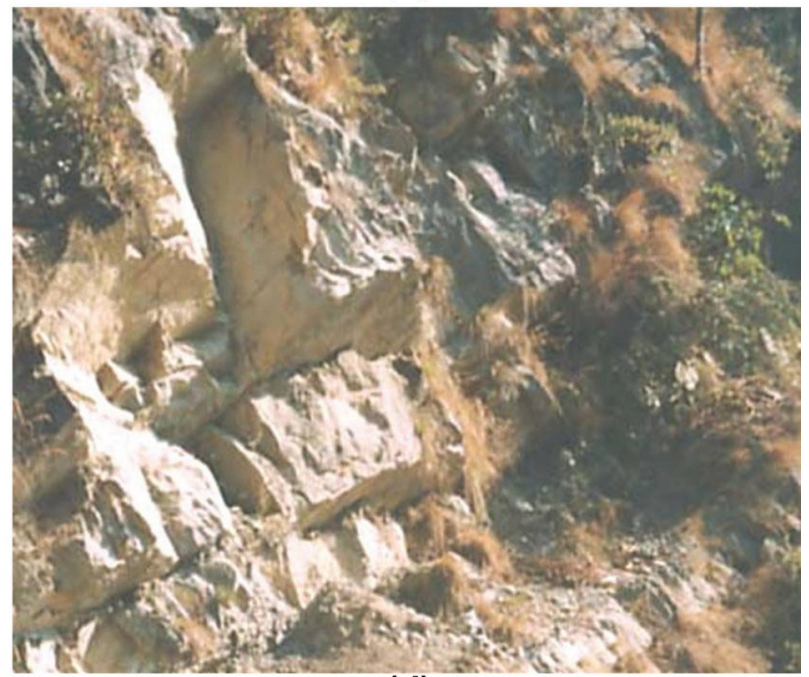

(d)

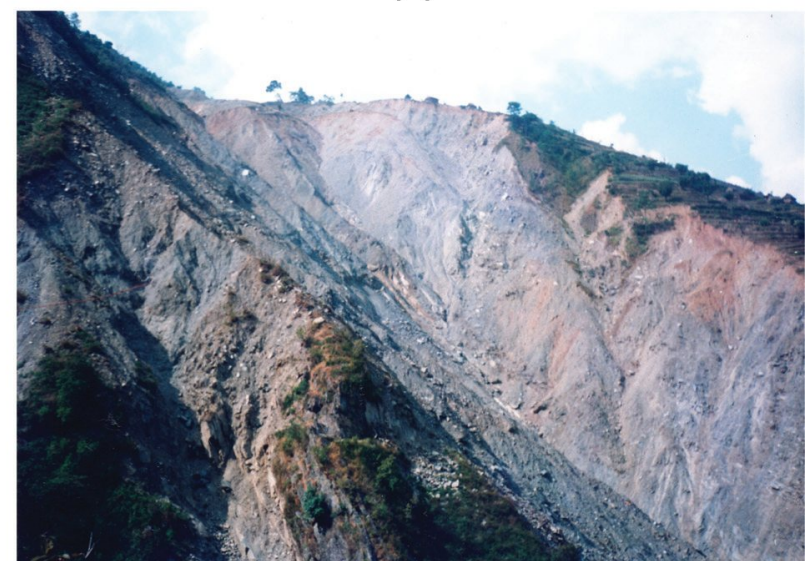

(f)

Fig. 4: Topographic and geologic cause for landslide initiation in Nepal (a) slope gradient (Thapa 2011), (b) shear zones at Main Boundary Thrust (MBT), (c) orientation of discontinuity in the direction of slope-face, (d) intersection of joints forming unstable wedge, (e) high degree of jointing/fracturing, and (f) granular soil in steep hill-slope. 
orientation of hillslope indirectly affects other factors that contribute to landslides, such as precipitation, soil moisture, vegetation cover and soil thickness (Fernandes et al. 2004).

The landslides in Nepal are densely distributed in close proximity to the major faults/thrusts or linear boundary formed by competent and incompetent strata (Fig. 4b). When excavations are made into dip slopes or slopes with upward inclined strata, potential planes of weakness are truncated and exposed. These are called out-of-dip, or daylighted cut slopes. Many dip slope failures are ascribable to strain incompatability between materials of contrasting permeability or stiffness, such as sandstone and shale. Dip slope conditions are also created by inclined discontinuities, such as systematic or secondary valley-side joints; especially in strongly foliated rocks, such as schist. Dip slope failure caused by surcharging slope with unkeyed fill and excavating toe of slope for development. Many landslides in mountain hill-slopes are originating as planar slides at initiation point (Gerrard 1994) and converted into debris slide to flow which generally moves in downslope with high velocity (Fig. 4c). Foliations dipping back into slope or vertically stratified strata often undergo massive toppling failures along inclined joints and intersection of joints lead to the wedge failure (Fig. 4d).

Different lithologies have varied sensitivities to active geomorphological processes such as landslides (Carrara et al. 1991). In heterogeneous material or rock, the steeper slopes are associated to more strong geotechnical features and are consequently more stable but the occurrences of landslide don't depend on lithology only because other factors such as slope complexity, slope gradient etc. play the significant role in distribution pattern of landslides i.e. geometric relationship between the slope angle and orientation of discontinuities is the significant contributing factor for slope instability. Thus, effect of strata and structure association is found to be the most influencing in the slide-prone areas.

Rock weathering, jointing, and fracturing (Fig. 4e) lead to slope failures that may have been accelerated by a complex interplay of active tectonic and climatic forcing factors in Nepal. Soil dynamics is another factor, most often the presence of incoherent granular soil in steep mountain slopes and usually characterised by frequent slope failures due to less inter-particles cohesion of the soil (Fig. 4f) and fine soil or swelling clayey soil shows much complex behaviour in landsliding. With highlighting the landslides in terms of topographic and geologic control, the landslides occurrences in distinct geological sub-divisions of the Nepal Himalaya and their characteristic features are further described as:

\section{(a) Sub-Himalaya (Siwaliks)}

The Sub-Himalaya is made up of sedimentary rocks such as shale, mudstones, sandstones, siltstones and conglomerates which are generally very soft, loosely packed and can easily disintegrate. The mudstones have a strong swelling property and can flow when saturated with water. The sandstones are not so well compacted and cemented and can easily be weathered. The conglomerates are also very loose and are almost unconsolidated. The rocks of Sub-Himalaya are profusely jointed and faulted and intermittently folded. A number of eastwest trending thrusts occur within the Sub-Himalaya (Upreti 2001). All these geologic conditions are highly susceptible for different types of mass movements. The roads passing through this zone in Nepal are known for their high risk for large landslides and unstable cut slopes (e.g. frequent occurrence of slides close to Sidhhababa Temple near Butwal). Due to their weak geologic characters, mitigation of landslides in the SubHimalayan Zone is very complicated.

\section{(b) Lesser Himalaya}

The Lesser Himalaya comprises the Mahabharat Range, Midlands, and Fore-Himalaya; and occurrence of landslides in these sub-zones vary according to their topographical and geological characteristics;

Mahabharat Range is the first effective mountain barrier of the monsoon clouds and greatly influences the rainfall distribution pattern in Nepal. Due to the very steep slopes and inherently weak geologic condition, the range is highly susceptible for landslides. High amount of rainfall and occasional cloudbursts in this range acts as triggers to cause landslides and therefore, Mahabharat Range is generally dotted with large landslides (Upreti 2001) and periodically causes big disasters in this range (Upreti and Dhital 1996). The Mahabharat Range consists of rocks such as limestone, dolomite marble and granites, the slopes are more stable. The presence of rocks such as phyllites, slates, thinly bedded interlayering sequences of phyllites and quartzites make the terrain most vulnerable to landslides. The intense weathering that occurs in the region makes the rocks still weaker and prone to landslides (Upreti 2001).

Midlands have a subdued topography and the slopes are comparatively less steep than in other zones. However, the rocks in the Midlands are deeply weathered and thick soil formations are found in most hill slopes. These soils are generally prone to landslides especially where the deforestation is more intense. Most part of Midlands receives rainfall between 1000 and $2000 \mathrm{~mm}$ with some exceptionally high precipitation pockets. Depending upon the rock types and their structures, Midlands may have areas with high frequency of landslides (Upreti 2001). The bottom of the valleys of major rivers is particularly prone to landslides as the river under-cuttings are very common in such cases. Midland hosts most hill population of Nepal with a very high density. This physiographic unit is most intensively cultivated, using even the steepest slopes. Deforestation is most critical in this zone. Wherever possible, irrigation facilities are brought for rice cultivation in the terraces. Due to high density of population, in the Midlands the anthropogenic influence in causing landslides cannot be underestimated. It may also be noted that most good agriculture land in the hills of Nepal lie on old landslides as the failed mass of the landslides makes the terrain with gentler slope and more moist. In such areas improper methods of irrigation or constructions of new roads and canals invariably trigger the reactivation of the landslides threatening the entire slope (Upreti 2001). 
Fore Himalaya starts as the Midlands gradually pass to the north and even further north to the Higher Himalaya. The rocks of Fore Himalaya are phyllites, schists, marble, quartzites, and gneisses. As this physiographic is presently uplifting at a high rate, the topography is steep and rugged. Therefore, the slopes become more unstable. This zone receives very high annual precipitation generally ranging between 2000 and $3000 \mathrm{~mm}$ (Chalise et al. 1996, Upreti and Dhital 1996). Depending upon the nature of the rocks, extent and distribution of landslides vary. One of the very interesting aspects of the Fore Himalaya is the presence of thick bouldary soils on its slopes generally known as the colluvium (Upreti 2001). A number of landslides were occurred in the past as well as triggered by 2015 Gorkha Earthquake along the Arniko Highway. The thickness of these soils is normally very high. Similar soils and associated landslides can be found along most of the north-south flowing major rivers of Nepal. There are also areas in this unit along narrow major river valleys where large part of the hills collapse towards the centre of the valley producing catastrophic landslides (e.g. 2014 Jure Landslide at Sunkoshi River).

\section{(c) Higher Himalaya}

The Himalaya Himalaya forms the highest ranges exceeding $5000 \mathrm{~m}$ in altitude. The rocks of this zone are gneisses, migmatites, schists, marbles, and quartzites and have undergone metamorphism at a very high temperature and pressure. These rocks are comparatively strong and can form very high steep slopes. The topography of this zone is the most rugged and steep among all the physiographic units. The southern face of the Higher Himalaya generally receives high precipitation. Although the rocks of the Higher Himalaya is supposed to be very strong due to their high grade metamorphic origin, nevertheless, they are subject to landslides of various sizes and most of them are rock slides (Upreti 2001). Exceptionally large landslides are also reported in this zone. The Tsergo Ri landslide is a mega-landslide in the Langtang Valley in central Nepal with a displaced mass of $10 \mathrm{~km}^{3}$ (Weidinger and Schramm 1995) and also the landslide avalanche triggered by the 2015 Gorkha Earthquake buried almost the entire valley of Langtang.

\section{(d) Tibetan-Tethys Himalaya}

Tibetan-Tethys Himalaya lies in the rain shadow zone of the Himalaya in which the average annual rainfall is less than $250 \mathrm{~mm}$. Therefore, the landslides are not frequent in contrast to southern side of the Himalaya. The common type of landslides may be considered as the failure of colluvial and moranic materials along the steep slopes of the valley (Upreti 2001).

\section{Triggering control and human intervention}

Geo-hazard studies showed that rainfall, earthquake human engineering activities have the significantly triggering the landslides. One of the primary triggers for shallow landslides on soil mantled landscapes is high intensity and/or long duration rainfall (Caine 1980, Guzzetti et al. 2008). Many evidences showed that precipitation has infiltrated downward and forms perched water or saturated zones on top of impermeable layers, so as to reduce soil strength. Precipitation also adds to the weight of rock and soil mass, creates pore water pressure and reduces suction (Zhang and Liu 2010). The effective strength of the colluvial or thin residual soils is reduced, and thereby landslides are triggered. Shallow slides are usually triggered by short intense rainstorms whereas the deep-seated landslides are caused by long-duration rainfall event. Large-scale landslides can be also seen as landmasses in natural slopes that might have moved long ago (hundreds to thousands of years ago), and still retain the original slope form without complete collapse (Bhandary et al. 2013). Extreme weather events are common in Nepal during summer Monsoon season (Dhital et al. 1993), for example extreme weather event (with maximum rainfall of $440 \mathrm{~mm}$ in 24 hours) of 19-21 July 1993 was the key factor to causes the spatial localisation of landslides in the central Nepal (Fig. 5).

On 25 April 2015, the Gorkha Earthquake with Mw 7.8 triggered a large number of landslides with various types, including highly disrupted shallow slides, rock falls, and largescale avalanches (Fig. 6) whilst monsoon rain continues that may trigger numerous new landslides as the mountain slopes were already weakened by the Gorkha Earthquake and its heavy aftershocks. Thus, Nepal is located in seismically active belt of the Himalayas and earthquake is another major dynamic factor that can trigger a large number of landslides but from the statistical point of view, precipitation is a much more important triggering factor than earthquakes (Bertolini 2010).

Among the factors contributing landslides, human activities are the easiest to manage and change. A number of landslides occurred along the highways and road corridors of Nepal (Fig. 7a); the road is considered to increase the probability of landslides in hilly terrains as a result of undercutting and the application of surcharges which is particularly true in places where the topographic slope and the dip of the beds are in conformity (Petley 2007). Thus, landslides are highly localised along the major highways as well as in recently expanding rural roads that significantly increases the losses and damages. Deoja (1994) estimated that 400-700 cubic meters of landslides occurs per kilometre per year along the mountain roads and 3000 to 9000 cubic meters of landslide occurs per kilometre during the construction of mountain roads in Nepal. In attempt to reopen the damaged roads, the alignment is always shifting towards hill-side which further destabilises the fragile colluvial slope (Adhikari 2001). With fast economic development, human engineering activities have become ever more intensive and prominent. Usually most engineering works are carried out in dry seasons when steep slopes can be created. These remain stable until the next rainy season or longer, and may become unstable after an exceptionally wet period or because of other triggering factors (Zhang and Liu 2010). Moreover, human activities like mining, quarrying etc. are also aggravating the hill-slopes which ultimately accelerates the landslides process (Fig. 7b). 


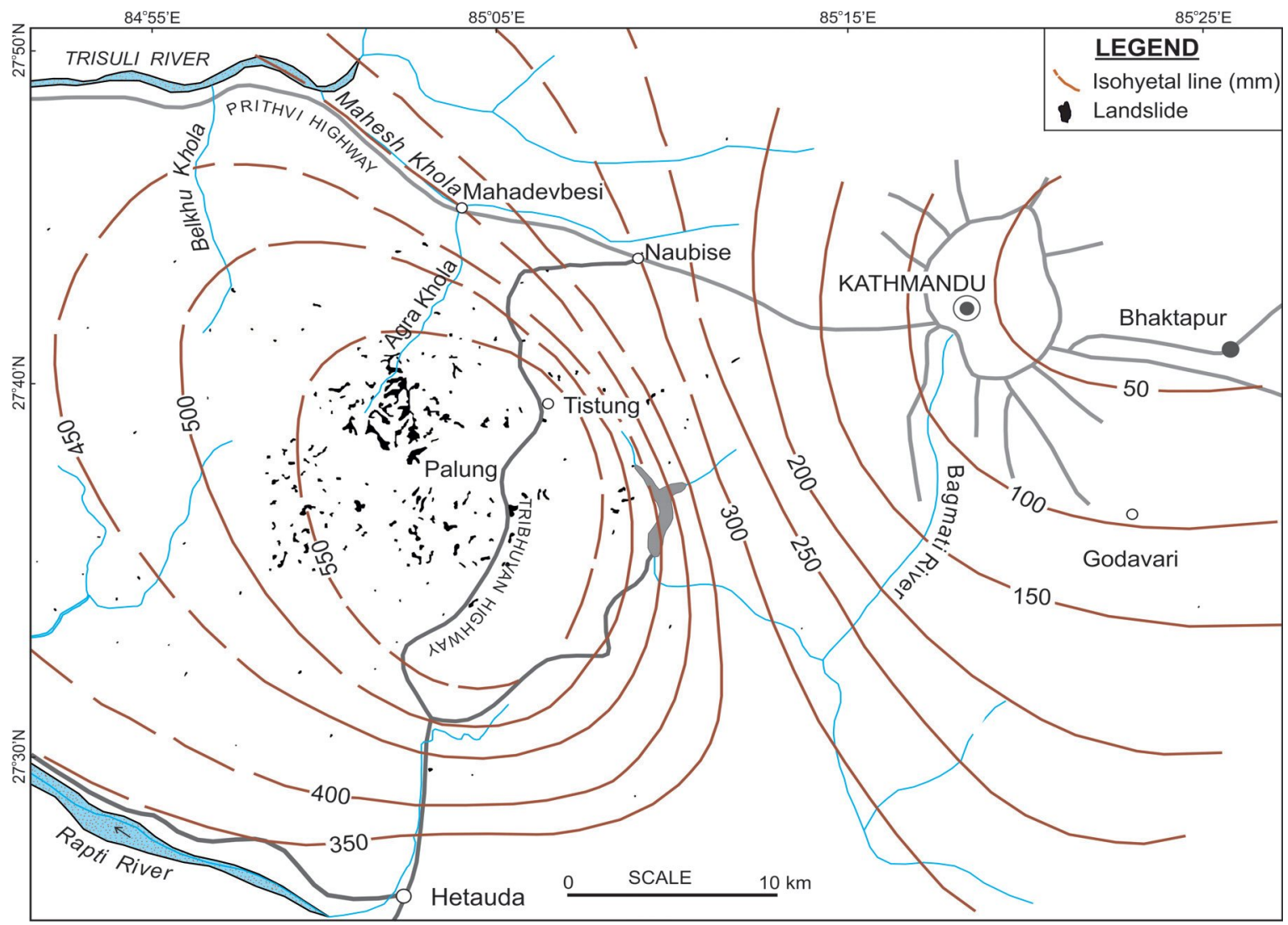

Fig. 5: Rainfall triggered landslides (isohyetal map showing 24-hour rainfall of extreme weather events during 19-21 July 1993 and occurrence of landslides in the central Nepal). (Source: DHM)

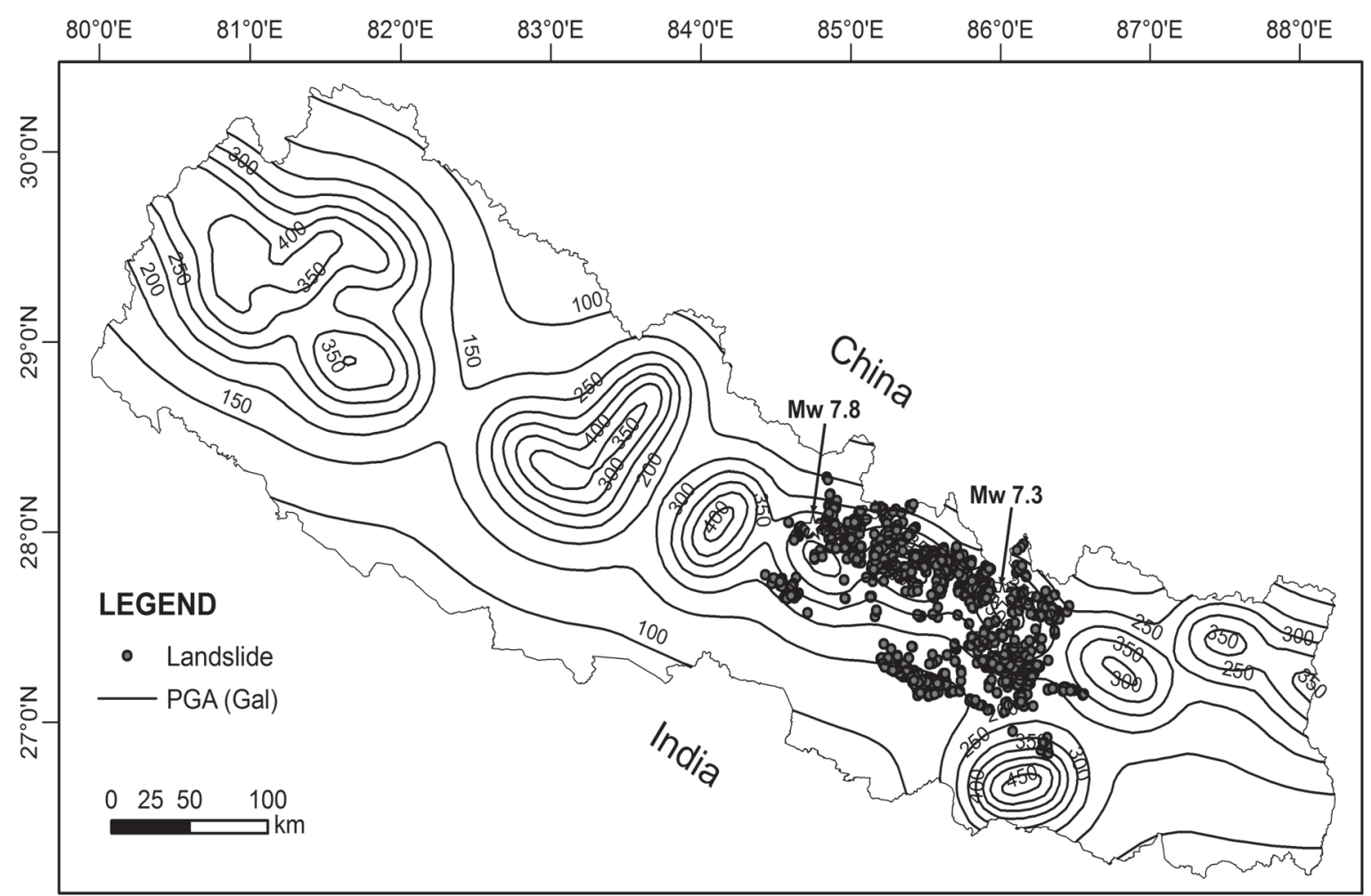

Fig. 6: Earthquake triggered landslides (preliminary inventory), Mw 7.8 2015 Gorkha Earthquake and occurrence of landslides in the central Nepal and overlaying with peak ground acceleration (PGA) values of Nepal (Source: Department of Mines and Geology, Nepal). 


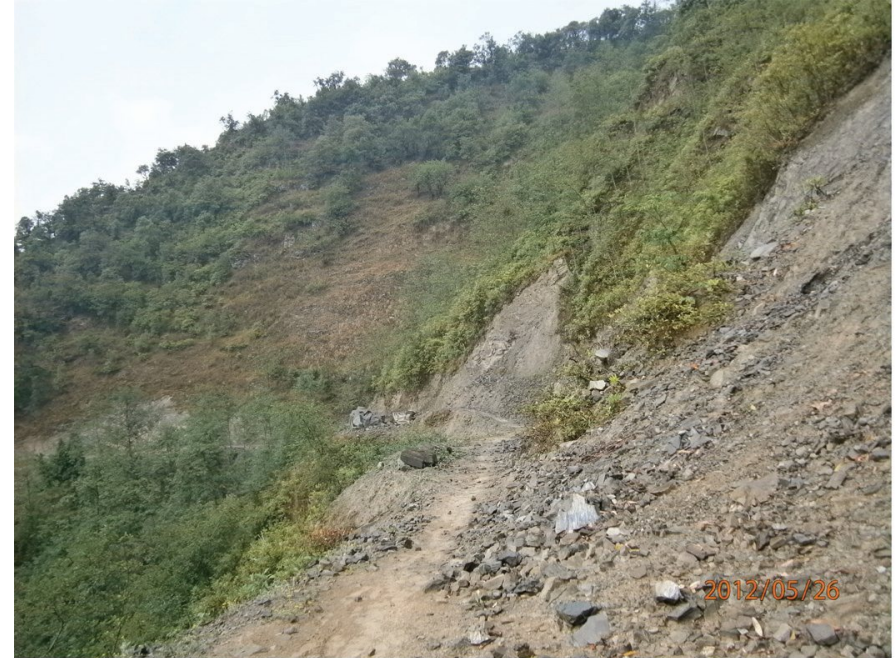

(a)

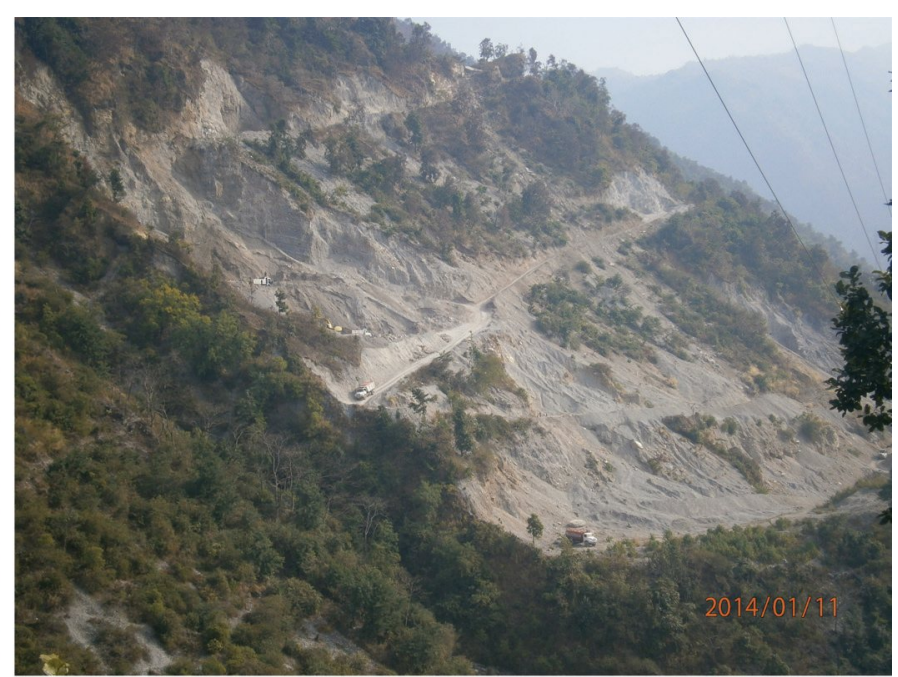

(b)

Fig. 7: Human intervention and landslide occurrences (a) road construction without due consideration of engineering geological conditions and (b) quarrying/mining activities.

\section{LANDSLIDE MITIGATION OPTIONS}

Landslide mitigation requires cause and characteristics of landslides in regional and site specific level in order to implement different kinds of mitigation techniques because the geology of the Nepal is weak and in the phase of stabilisation, even a small wrong development can cause the destabilisation of the natural environment (Mulmi 2009). Each of the major geological sub-divisions (from south to North: Sub-Himalaya, Lesser Himalaya, Higher Himalaya and Tibetan-Tethys Himalaya) in Nepal is characteristically different than others. Therefore a uniform approach of study and mitigation of landslide hazard may not be applicable in every zone of the Himalaya (Upreti 2001). For example the landslide problem of Siwaliks (Sub-Himalaya) is unique and entirely different from that of the Lesser Himalaya and Higher Himalaya. Similarly, the nature of problem in the Higher Himalaya is quite different than rest of other Himalayan zones. A better understanding of the geologic, physiographic and climatic zones and their combined overall effects on the terrain is a prerequisite for any successful efforts on landslide study and mitigation in Nepal (Upreti 2001). A detailed hydro-meteorological data through a better network will greatly support the precise assessment of rainfall effect on landslide occurrences as well as GPS monitoring can predict probability of future earthquakes that will trigger landslides.

Investigating the causes of the landslide helps to suggest possible mitigation options, the common field investigations and measurements can be surficial investigations (engineering geological mapping, geodetic measurements, geophysical measurements, measurements of surficial deformations on the landslide surface, etc.), and subsurface investigations and investigations in boreholes (ground water table measurements, determining the depth of sliding, water permeability tests, geomechanical tests on the cores, in-situ geomechanical tests etc.). Testing for soil strength parameters $(\mathrm{c}, \phi)$, unit weights $(\gamma)$, unconfined compression, triaxial, point load, joint friction, etc. is useful to calculate factor of safety. The critical importance is to look carefully the bedrock creep zone which always exists on sloping ground and water percolates through this zone. Temporary back-cuts should be inspected by looking for physical evidence of active seeps along the contact between the weathered bands and unweathered zones. Evidence of past seepage, such as carbonate (caliche) is also valuable. The practice of geotechnical instrumentation is still innovative in roadside slope stabilisation in Nepal (Adhikari 2014). Monitoring of various parameters is crucial to assess the effectiveness of the applied measures in the landslides which includes movement monitoring, subsidence monitoring, cracks monitoring, stress monitoring, stage or discharge monitoring, water table monitoring etc. Furthermore, the appropriate assessment of soil and rock characteristics is crucial to solving geotechnical roadside problems. The characterisation of the relevant soil or rock mass, as opposed to their constituent materials, is of importance in problems concerned with slope instability and related structures. The distinction between material and mass properties is closely related to the influence of discontinuities (DOR/GESU 2009). The practitioner engineer must be careful to distinguish between the intact material and that of a blocky discontinuous matrix since the overall behaviour of rock mass is often influenced by discontinuities rather than by intact rocks.

Frequent failure of retaining walls along roadsides were due to inappropriate design of wall to resist the subjected loads and thus retention system has to be evaluated for local and global stability because the global stability usually controls the design in landslide mitigation. The most critical mechanism of slope movements is the water infiltrating into the overburden materials during heavy rains and resultant increase in pore 
water pressure. The behaviour of the groundwater flow and their distribution in different layers within the landslide mass can be numerically simulated to install preventative measures, like horizontal drains, to prevent occurrence of disastrous landslides (Shrestha et al. 2014). An integrated approach to understand the sliding mechanism can provide affordable and pragmatic solutions for landslide control or mitigation strategies.

\section{Slope stabilisation practices in Nepal}

The efforts of slope stabilisation in Nepal have been practiced in different sectors but more common in road corridors to deliver efficient transport services. The advancement of geotechnical practices in Nepal developed together with the era of infrastructural development during post 1950 and the later half of the twentieth century witnessed a considerable expansion of road network with assistance from bilateral agencies (Adhikari 2014). Post construction management of the landslides entirely relies on the routine maintenance system. A novel solution to the system for such management is yet to be evolved. Over simplified approaches to landslide controls under routine maintenance of highway alone are not sufficient which may lead to conflict of interest with the local population.

The approach and guidelines for slope stabilisation works, mostly along road corridor, are suggested in Guide to Slope Protection (DOR/GESU 2003) and the latest Road Side Geotechnical Problems: A Guide to Their Solution (DOR/ GESU 2009) on which periodic trainings are imparted to engineers involved in slope stabilisation and mitigation works. Post mitigation measures of landslides in road corridor are very common cases for most of the mountain roads constructed in Nepal during the last some decades. It is important to develop low cost engineering solutions to instability that are within the capability of indigenous resources in terms of materials, institutional organisation and manual skills (Brooks and Lawrance 1986) and for which mortared-framed wall successfully implemented as low-cost techniques (Fig. 8a). To protect the road pavement and side drains, most common engineering measures practiced in the early days of road projects in Nepal are toe walls and cut-off drains (Brooks and Lawrance 1986). Efforts of DOR for low cost techniques by applying vegetation and surface drainage system (Fig. $8 b$ ), however, have reduced some chance of further failure. Adhikari (2001) highlighted the slope stabilisation measures in the Arniko Highway (a major trade link between Nepal and China) which is the most affected highway indicated by the frequency of landslides and bank erosions. Some examples of effective use of lowering of groundwater by slightly inclined horizontal boreholes in Arniko Highway (Fig. 8c) but these are greatly limited and must be implemented several landslides in the different locations of the highway. Furthermore, Adhikari
(2014) analysed the various types of landslide mitigation works along the highways and roads in the different parts of the country. The bioengineering, drainage, and geotechnical measures were extensively used along the road combined with labour-intensive road construction practices. In addition to the replication of successful measures from DharanDhankuta and Lamosangu-Jiri roads, further innovative geotechnical solutions applied in the roads included various forms of composite revetment structures, different types of spurs with face block protection, launching aprons with composite frames or articulated concrete blocks, boulder riprap, boulder armouring using interconnected boulders, rock fall netting etc. Quite a good number of geotechnical practices were introduced and advanced in the construction of Japanassisted Bardibas-Sindhuli-Banepa Highway. Extensive use of geogrids, reinforced earth, ground anchors, horizontal drains, diverse foundation types, and river training works were applied in the road projects in conjunction with bio-engineering measures (Adhikari 2014). An example of retaining walls, rock anchoring, surface, and subsurface drains can be found along the Naubise and Thankot road section (Fig. 8d).

\section{Evaluation of mitigation techniques}

Avoiding of landslides is an important step in reducing of impact of landslide which is even not completely free of hazard and risk in Nepal because many villages are situated on or adjacent to past landslides. The landslides are common phenomena of geomorphic evolution in the mountain hillslopes and therefore, it is very important to live with risk and to evaluate varieties of mitigation techniques with success and failure. Lesson learnt from previous and ongoing practices, some of the techniques can be implemented in Nepal more effectively and evaluation of appropriate mitigation measures should be based functional knowledge on the technical feasibility and costs and benefits of risk-reduction efforts. In many situations, technical experts face difficulties to choose the most "appropriate" set of mitigation and prevention measures because the complexities and technical details of managing landslide risk can easily be hindered by any strategy which is embedded in a socio-political system. A proper stabilisation measure depends on site-specific conditions such as the size and activity slide, soil type, topography constraints, and the cause of failure. The important aspect should not be overlooked in order to ensure the longevity of the mitigation works. For large landslides, the intended mitigation works are normally a combination of different control and proposed restraint works, and their construction is rather timely and physically complex, usually executed in phases. In most excavation and embankment works, relatively flat slopes, good compaction, and adding needed drainage will typically eliminate routine instability problems.

Among the most common methods of mitigation techniques, the subsurface drainage of landslide slopes is the most suitable by using horizontal drainage borehole (HDB). The advantage of this method lies in its quick effectiveness 


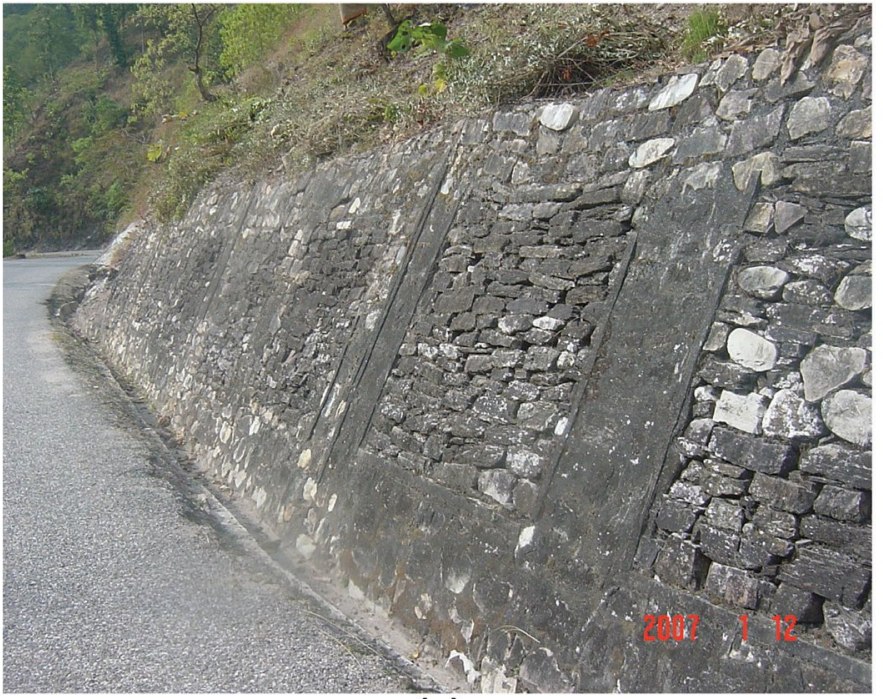

(a)

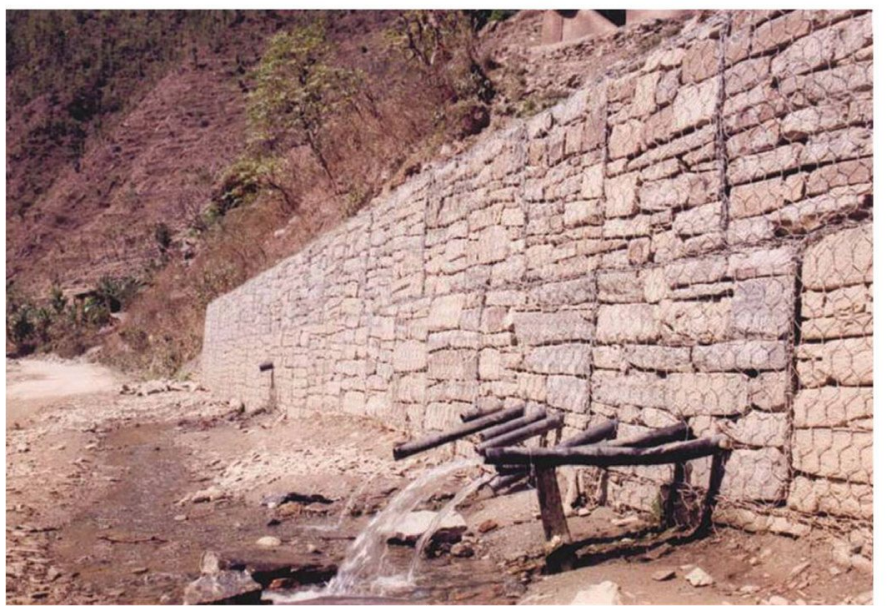

(c)

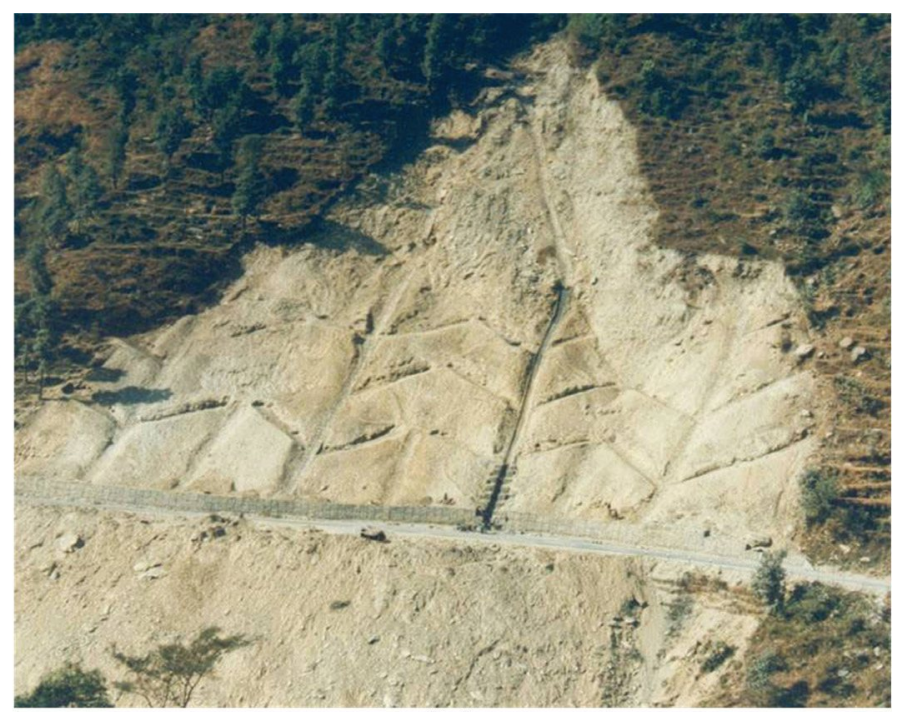

(b)

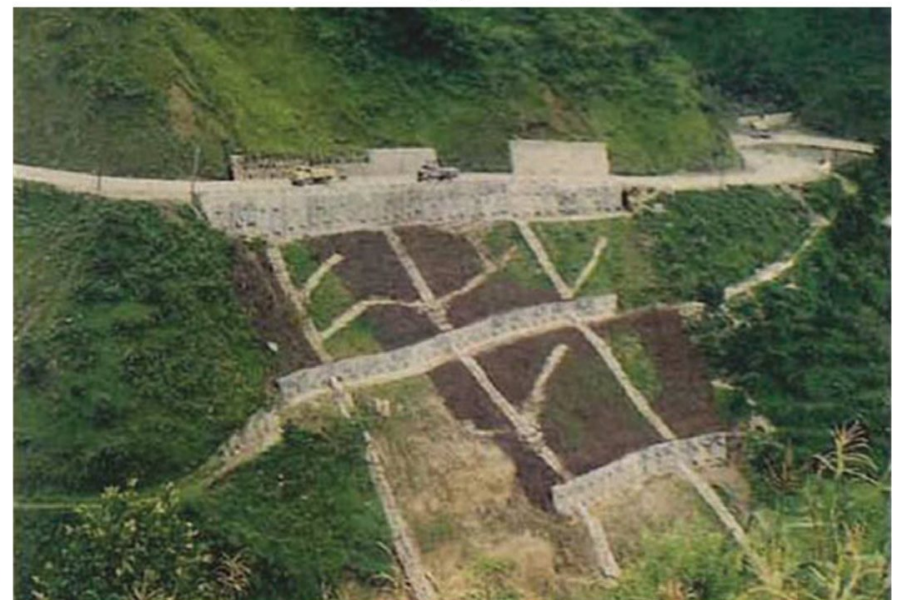

(d)

Fig. 8: Slope stabilisation practices in Nepal (a) mortared frame masonry wall, (b) surface drainage, (c) gabion wall with installed horizontal drains and (d) retaining walls and rock anchorage.

and relatively low cost (Kopecký et al. 2013). HDB efficiency is the best if the horizons are captured, especially in the upper parts of the slope where the effect of the water hydrostatic pressure reduction contributes most to the slope stability. They are effective also for drainage of groundwater gathered on a dilatational slip surface of landslides (Kopecký et al. 2013). On the other hand, it is not suitable to use HDB in thick layers of fine-grained (pelitic) rocks with low permeability. Lots of horizontal boreholes is necessary to install in such case, because the areal coverage of one HDB in such material is very small. Great care must be taken when using HDB for remediation of deep landslides not only in pelitic, but also in strongly weathered and broken semi-hard rocks (Kopecký et al. 2013). The simulation of pore water pressure distribution at the slip surface during low and high rainfall periods helps to identify the critical locations with higher pore water pressure even during low rainfall periods (Shrestha et al. 2014). Such areas can be considered prime locations for implementation for future dewatering activities. In the long-term, the horizontal drains may be ineffective or show poor performance due to clogging of the perforated pipes in clayey soil (Topal and Akin 2009).

For low to high walls in many geographic areas today, mechanically stabilised embankment (MSE) or "Reinforced Soil" structures are the least expensive type of wall available (Keller and Sherar 2003) because of simplicity to build and often use on-site granular backfill material. Driven piles with or without tiebacks, are relatively expensive but are often the most environmentally acceptable type of wall and cause less site disturbance than gravity or MSE structures that require a large foundation excavation.

A reality of landslide mitigation works in Nepal is that thousands of landslides occur suddenly after the extreme weather events (e.g. 1993) or devastating earthquake (e.g. 2015) that complicates to implement mitigation measures without proper investigation as well as in very limited time frame. Thus, low cost and rapidity of works is always crucial 
issues which involve the sealing of tension cracks surrounding the crown or either sides of the landslide, removing unstable debris, making surface drainages, and bamboo plantation. However, detailed monitoring and investigation needs to be greatly prioritised to implement suitable mitigation options for the community resilience in the landslide prone areas of Nepal because the landslide is the greatest challenge for relocation of displaced people and any reconstruction strategies.

\section{DISCUSSION AND CONCLUSIONS}

Frequent occurrences in the Nepal are attributed to rugged topography, fragile geology, extreme weather events, haphazard land use planning (e.g. settlement in steep hillslope, improper road construction) and that have been affected development infrastructures, lives, and properties of the people every year. Landslides are spatially localised in steep slopes river valleys, close proximity to thrust faults or boundary between competent and incompetent rock strata. Dip-slope conditions of major discontinuities are the main cause of landslide along the road corridor in Nepal because the roads often encounter such daylight situations due to geological complexities (e.g. faulted/folded rock strata). The lack of a proper methodology or insufficient attempts to deal with the landslide susceptibility/hazard have resulted the ever increasing number of landslides in the mountain hill-slope which are especially evident along the roadsides. Some investigations and mitigation measures carried out by practitioner engineers and researchers in Nepal are still inadequate to deal with landslide risk reduction measures. Frequent reactivation of landslides during the rainfall or earthquake events clearly showed that already documented and practiced landslide mitigations are either inadequate or not properly implemented in Nepal. Thus, evaluation of landslides characteristics in differential geoenvironment and lesson learnt from the mitigation practices have helped to suggest landslide mitigation options.

Increase in pore water pressure is the main cause of landslides initiation in mountain hill-slope, the management of surface and subsurface water is the most efficient stabilisation measures for landslides. Surface drainage can controls the percolation of surface water and discharge water effectively outside of the landslide area which can be done with lined catch drains and riprap channels. Inclined horizontal drains can be used to intercept seepage back beneath undisturbed ground or used to convey discharge from other drainage measures, which are benefit of gravity outlets. Drainage wells have been widely used as a landslide control works, quite often in combination with horizontal drain borings in order to drain groundwater even more effectively. Structural measures are recommended as next priority and can be applied where drainage alone is inefficient. The protective measures with combination of drainage works and retaining walls are more effective solution for landslide. Various support systems and elements can be combined to craft creative solutions for slope instability problems. Mechanically Stabilised Embankment (MSE) is also cost-effective soil-retaining structures that can tolerate much larger settlements than reinforced concrete walls. Bioengineering is another environmental friendly technique with high degree of success in shallow and moderately active landslides. Therefore, the combined effort of drainage, bioengineering, and structural measures are suitable wherever feasible from economic and engineering geological point of views. Tensile soil reinforcement can also be applied to landslide control work, allowing selective reinforcement of limited zones. Specialised support structures such as rock bolts, earth anchors, soil anchors etc. are suggested only at locations where partial excavation, use of horizontal, and bioengineering measures are not the suitable mitigation options.

\section{ACKNOWLEDGMENTS}

The author is grateful to Ram Prasad Sharma and another anonymous reviewer for their constructive comments to improve the manuscript.

\section{REFERENCES}

Adhikari, T. L., 2001, Landslide control and stabilization measures in Arniko Highway, central Nepal. In: Landslide hazard mitigation in the Hindu Kush-Himalayas, Tianchi, L., Chalise, S. R. and Upreti, B. N. (eds.), ICIMOD publication, pp. 31-49.

Adhikari, T. L., 2014, Geotechnical Practices in Nepal. International Symposium Geohazards: Science, Engineering and Management, November 20-21, 2014, Kathmandu, Nepal, pp. 114-127.

Aleotti, P. and Chowdhury, R., 1999, Landslide hazard assessment: summary review and new perspective. Bull. Eng. Geol. and Envir., v. 58, pp. 21-44.

Bertolini, G., 2010, Large earth flows in Emilia-Romagna (Northern Apennines, Italy): origin, reactivation and possible hazard assessment strategies. Z. dt. Ges. Geowiss., v. 161/2, pp. 139-162.

Bhandary, N. P., Yatabe, R., Dahal, R. K., Hasegawa, S. and Inagaki, H., 2013, Areal distribution of large-scale landslides along highway corridors in central Nepal. Georisk: Assessment and Management of Risk for Engineered Systems and Geohazards, DOI:10.1080/174 99518.2012.743377, i First version.

Brooks, D. M. and Lawrance, C. J., 1986, Maintenance of roads in hilly areas - experiments on road cuttings in Nepal.PTRC, Summer Annual Meeting, University of Sussex, 14-17 July 1986, Proc. of Seminar J., London: PTRC Education and Research Services, pp. 37-53.

Caine, N., 1980, The rainfall intensity-duration control of shallow landslides and debris flows. Geografiska Annaler Series A-Physical Geography, v. 62(1): 23-27.

Carrara, A., Cardinali, M., Detti, R., Guzetti, F., Pasqui, V. and Reichenbach, P., 1991, GIS techniques and statistical models in evaluating landslide hazard. Earth Surface Processes and Landforms, v. 16, pp. 427-445. 
Chalise, S. R., Shrestha, M. L., Thapa, K. B., Shrestha, B. R. and Bajracharya, B., 1996, Climatic and hydrological atlas of Nepal. ICIMOD, Kathmandu, 264 p.

Chhetri, M. P. and Bhattarai, D., 2001, Mitigation and management of flood in Nepal, Kathmandu. Ministry of Home Affairs.

Dahal, R. K. and Hasegawa, S., 2008, Representative rainfall thresholds for landslides in the Nepal Himalaya. Geomorphology, v. 100, pp. 429-443.

Deoja, B. B., 1994, Sustainable approaches to the construction of roads and other infrastructure in the Hindu KushHimalayas. International Centre for Integrated Mountain Development (ICIMOD) Occasional paper, 24, Kathmandu, 70 p.

Department of Mines and Geology (Pandey, M. R., Chitrakar, G. R., Kafle, B., Sapkota, S. N., Rajaure, S., Gautam, U. P.), Seismic Hazard Map of Nepal published by National Seismological Centre, Department of Mines and Geology, Kathmandu, Nepal.

DesInventar, (http://www.desinventar.net/DesInventar/ profiletab.jsp? countrycode $=\mathrm{npl}$ ), DesInventar Database for Nepal.

Dhital, M. R., Khanal, N. R. and Thapa, K. B., 1993, The role of extreme weather events, mass movements, and land use change in increasing natural hazards. International Centre for Integrated Mountain Development (ICIMOD), Kathmandu, Nepal, 41 p.

DHM, (http://www.dhm.gov.np/), Department of Hydrology and Meteorology (DHM), Nepal.

DoR/GESU, 2003, Guide to Road Slope Protection Works. Department of Roads (DOR)/Geo-environmental and Social Unit (GESU), Kathmandu, Nepal.

DOR/GESU, 2009, Roadside Geotechnical Problems: A Guide to their Solution. Department of Roads (DOR)/Geoenvironmental and Social Unit (GESU), Kathmandu, Nepal.

DWIDP, (http://www.dwidp.gov.np/) Department of Water Induced Disaster Prevention, Nepal (DWIDP), Government of Nepal.

Fernandes, N. F., Guimarães, R. F., Gomes, R. A. T., Vieira, B. C., Montgomery, D. R. and Greenberg, H., 2004, Topographic controls of landslides in Rio de Janeiro: field evidence and modeling. Catena, v. 55, pp. 163-181.

Gerrard, J., 1994, The landslide hazard in the Himalayas: geological control and human action. Geomorphology, v. 10(1-4), pp. 221-230.

Guzzetti, F., Peruccacci, S., Rossi, M. and Stark, C. P., 2008, The rainfall intensity-duration control of shallow landslides and debris flows: an update. Landslides, v. 5(1), pp. 3-17.

Keller, G. and Sherar, J., 2003, Low-Volume Roads Engineering Best Management Practices Field Guide. USDA Forest Service; US Agency for International Development;
Conservation Management Institute, Virginia Polytechnic Institute and State University, $158 \mathrm{p}$.

Kopecký, M., Ondrášik, M. and Antolová, D., 2013, Horizontal Drains as Effective Measure for Landslide Remediation. Studia Geotechnica et Mechanica, v. XXXV(1), pp. 129141.

Lei, Z. and Jing-feng, H., 2006, GIS-based logistic regression method for landslide susceptibility mapping in regional scale. Jour. of Zhejiang University Science, v. 7, pp. 2007-2017.

LRA/DoLIDAR/Scott Wilson, 2002, Map of Landslide Distribution in Nepal 1968-2002. Landslide Risk Assessment in the Rural Access Sector, DoLIDAR/Scott Wilson.

McKean J. and Roering J., 2004, Objective landslide detection and surface morphology mapping using high-resolution airborne laser altimetry. Geomorphology, v. 57, pp. 331351 .

MoHA, http://drm.moha.gov.np/ Ministry of Home Affair (MoHA), Nepal.

Mulmi, A. D., 2009, Green Road Approach in Rural Road Construction for the Sustainable Development of Nepal. Journal of Sustainable Development, v. 2(3), pp.149165.

Petley, D. N., Hearn, G. J., Hart A., Rosser N. J., Dunning, S. A., Oven, K. and Mitchell, W. A., 2007, Trends in landslide occurrence in Nepal. Nat. Hazards, v. 43, pp. 23-44.

Shrestha, H. K., Yatabe, R. and Bhandary, N. P., 2014, Investigation of Causes of Variation in Effectiveness of Horizontal Drains as a Landslide Remediation Measure. International Symposium Geohazards: Science, Engineering and Management, November 20-21, 2014, Kathmandu, Nepal, pp. 245-251.

Thapa, P. B., 2011, Landslide susceptibility modelling in the central Nepal Lesser Himalaya. Z. dt. Ges. Geowiss., v. 162(4), pp. 405-420.

Topal, T. and Akin, M., 2009, Geotechnical assessment of a landslide along a natural gas pipeline for possible remediations (Karacabey-Turkey). Environ. Geol., v. 57, pp. 611-620.

Upreti, B. N., 2001, Physiography and Geology of Nepal and their bearing on the landslide problem. In: Landslide hazard mitigation in the Hindu Kush-Himalayas, Tianchi L., Chalise, S. R. and Upreti, B. N. (eds.), ICIMOD publication, pp. 31-49.

Upreti, B. N. and Dhital, M. R., 1996, Landslide studies and management in Nepal. International Centre for integrated Mountain Development (ICIMOD), Kathmandu, Nepal, $87 \mathrm{p}$.

Vijith, H., Rejith, P. G. and Madhu, G., 2009, Using Info Val Method and GIS techniques for the spatial modelling of landslides susceptibility in the Upper catchment of River 
Meenachil in Kerala. Indian Soc. of Remote Sensing, v. 37, pp. 241-250.

Weidinger, J. T. and Schramm, J. M., 1995, A short note on the Tsergo Ri landslide, Langtang Himal, Nepal. In: Upreti, B. N. and Dhital, M. R. (eds.), 9th Himalaya-Karakorum-
Tibet workshop, Kathmandu, Jour. of Nepal Geol. Soc., v. 11 (Sp. Issue), pp. 257-272.

Zhang, M. and Liu, J., 2010, Controlling factors of loess landslides in western China. Environ. Earth Sci., v. 59, pp. 1671-1680. 